\title{
Universiteit
}

Leiden

The Netherlands

\section{Discomfiture of democracy? The 2005 election crisis in Ethiopia and its aftermath}

Abbink, G.J.

\section{Citation}

Abbink, G. J. (2006). Discomfiture of democracy? The 2005 election crisis in Ethiopia and its aftermath. African Affairs: The Journal of The Royal African Society, 105(419), 173-199. Retrieved from https://hdl.handle.net/1887/9551

Version: $\quad$ Not Applicable (or Unknown)

License: $\quad$ Leiden University Non-exclusive license

Downloaded from: $\quad$ https://hdl.handle.net/1887/9551

Note: To cite this publication please use the final published version (if applicable). 


\title{
DISCOMFITURE OF DEMOCRACY? THE 2005 ELECTION CRISIS IN ETHIOPIA AND ITS AFTERMATH
}

\author{
J. ABBINK
}

\begin{abstract}
In this article, I assess the nature and the impact of the May 2005 Ethiopian parliamentary elections on Ethiopian politics. The elections, although controversial and flawed, showed significant gains for the opposition but led to a crisis of the entire democratization process. I revisit Ethiopian political culture in the light of neo-patrimonial theory and ask why the political system has stagnated and slid back into authoritarianism. Most analyses of post-1991 Ethiopian politics discuss the formal aspects of the political system but do not deal sufficiently with power politics in a historical perspective. There is a continued need to reconceptualize the analysis of politics in Ethiopia, and Africa in general, in more cultural and historical terms, away from the formal political science approaches that have predominated. The success of transitional democracy is also dependent on a countervailing middle class, which is suppressed in Ethiopia. Also, political-judicial institutions are still precarious, and their operation is dependent on the current political elite and caught in the politics of the dominant (ruling) party. All these refer back to the historically engrained authoritarian/hierarchical tradition in Ethiopian politics. On the basis of the electoral process, the post-election manoeuvring, the role of opposition forces, and the violent crisis in late 2005, I address the Ethiopian political process in the light of governance traditions and of resurrected neo-patrimonial rule that, in effect, tend to block further democratization.
\end{abstract}

THIS ARTICLE discusses the contested Ethiopian parliamentary elections of May 2005 and their aftermath and assesses the wider implications of the ensuing crisis in the country's political system. Although indicative of significant shifts in voters' preferences towards new opposition parties, the authoritarian political tradition in Ethiopia asserted itself again in the reluctance of the incumbent government to allow re-elections in contested

J. Abbink is affiliated to the African Studies Centre, Leiden, and Vrije Universiteit, Amsterdam. He thanks participants at the conference of the Netherlands African Studies Association ('Africa without Borders', Leiden, 29 October 2005), Klaas van Walraven (ASC Leiden), Christopher Clapham (Cambridge University), and two anonymous African Affairs referees for critical comments on a first version of this paper. Final editing was done in February 2006. 
constituencies or to hold dialogue with opposition groups, in rigid responses on the part of the opposition, and in violent repression of post-election dissent and mass arrests of perceived opponents. The elections were a step forward but did not signify a decisive, non-reversible move towards democracy because of the uncertainty about the counting procedures, the real results, and the controversial government response. Not only Ethiopian public, but also donor countries, and development partners, who invested a lot in the 'Ethiopian example', were greatly disillusioned. The 2005 elections and their aftermath thus revealed major constraints in Ethiopia's political system, underlining that after the regimes of Emperor Haile Sellassie (1930-74) and the military leader Mengistu (1974-91), centralist authoritarianism is not gone but perhaps is being reinvented in a new form.

There is no doubt that post-1991 Ethiopia saw significant political institution building and that a public ethos of democracy emerged. But the process is still closely controlled by the ruling Tigray People's Liberation Front-Ethiopian Peoples' Revolutionary Democratic Front (TPLFEPRDF), and has a high ingredient of rhetoric not backed by practice. In conditions of political insecurity and contested legitimacy, a network of political and economic control was built up by this party from its circle of trusted people, loyalists, and former comrades in the armed struggle. Thus, a selective hold on politics and economics in Ethiopia was established. There is a new, party-affiliated business class, and the non-party-affiliated business people regularly complain of unfair and non-transparent competition and preferential treatment. Most of the political decision-making seems to occur outside the cabinet of ministers and the parliament, as is evident at crucial moments. This informal, behind-the-scenes politics is nothing surprising in the Ethiopian, or wider African, context and is perhaps inevitable in a contested and risky political arena. It implies, however, that the durable constraints still in place within the political system have inhibited the development of a formal democratic structure that might lead to political power transfer.

As G. Gill has noted, ${ }^{1}$ it is important to analyse 'transitions' to democracy not only with a focus on the role of political actors and elites but also taking into account a wider array of social forces, for example class power, civil society groups, the stature and power (capacity) of the state, and transnational power connections. His study does not refer to African cases, but his model might be applied there as well. Since the mid-1980s, various related theoretical approaches have emerged to explain African politics and its problems: from the study of government and institutions, rational

1. G. Gill, The Dynamics of Democratization: Elites, civil society and the transition process (Macmillan Press, London, 2000). 
choice, ${ }^{2}$ and neo-patrimonialism ${ }^{3}$ to that of governance and regime transition. ${ }^{4}$ In recent years, there is more eye for the diversity, fragmentation, and conflictual nature of state and politics in Africa, as well as for social stratification, factors producing collapsed or failed states, ${ }^{5}$ and 'governmentality' in a more historical and cultural sense. ${ }^{6}$ Still relevant is the theory of neo-patrimonialism, which in Médard's definition (1996) emphasizes the specific link between the nominal features of a bureaucratic-legal state structure with personalized, 'traditionalist' forms of domination, via clientelistic networks and loyalties of ethnicity and kinship. But this perspective, which addresses durable features of African political systems often only reluctantly admitted, must be extended by giving more attention to politics as an arena of pluralist values and conflicting representations and practices of power. ${ }^{7}$ Finally, following Gill, ${ }^{8}$ the nature and range of civil society and the role of the business class in a country in 'transition' are to be taken into account.

\section{The meaning of elections in Ethiopia}

For comparative political scientists and political anthropologists, studying elections is a good entry point to explore the nature of politics and political manipulation in Africa. Elections have figured prominently in recent studies of 'democratic transition'. A discussion of the 2005 elections in Ethiopia and their aftermath must refer to the wider political and historical

2. R.H. Bates, Essays on the Political Economy of Rural Africa (Cambridge University Press, Cambridge, 1983); R.H. Bates (ed.), Towards a Political Economy of Development: A rational choice perspective (University of California Press, Berkeley, CA, 1998).

3. J.-F. Médard (ed.), 'L'État néo-patrimonial en Afrique noire', in États d'afrique Noire: Formations, mécanismes et crise (Karthala, Paris, 1991), pp. 323-53. J.-F. Médard, 'Patrimonialism, neo-patrimonialism and the study of the post-colonial state in Subsaharan Africa', in H.S. Marcussen (ed.), Improved Natural Resource Management: - the role of formal organisations and informal networks and institutions (Roskilde University, Institute of International Development Studies, Roskilde, 1996), pp. 76-97. M. Bratton and N. Van de Walle, Neopatrimonial regimes and political transitions in Africa, World Politics 46, 4 (1994), pp. 453-89.

4. G. Hyden and M. Bratton, Governance and Politics in Africa (Lynne Rienner, Boulder, CO, 1991); M. Bratton and N. van de Walle, Democratic Experiments in Africa: Regime transitions in comparative perspective (Cambridge University Press, Cambridge, 1997).

5. P. Chabal and J.-P. Daloz, Africa Works: Disorder as political instrument (Indiana University Press, Bloomington, and James Currey, Oxford, 1999); J. Milliken (ed.), 'State failure, collapse and reconstruction', Development and Change 33, 5 (2002), [Special issue].

6. For example, D.L. Donham, Marxist Modern: An ethnographic history of the Ethiopian revolution (University of California Press, Berkeley, and James Currey, Oxford, 1999); M. Karlström, 'Imagining democracy: political culture and democratization in Buganda', Africa 66, 4 (1996), pp. 485-505; M. Okema, Political Culture in Tanzania (Edwin Mellen Press, Lewiston, NY, 1996).

7. K.F. Hansen, 'The politics of personal relations: beyond neopatrimonial practices in northern Cameroon', Africa 73, 2 (2003), pp. 202-25; G. Erdmann and U. Engel, 'Neopatrimonialism reconsidered - critical review and elaboration of an elusive concept', paper presented at the 45 th Annual Meeting of the African Studies Association, Washington, DC, 4-8 December 2002.

8. Gill, Dynamics of Democratization. 
context and view the post-election political crisis with a longer term perspective that incorporates the country's political culture. After introductory sections on context and history, I start with a brief overview of what happened during and after the 2005 elections, a subject on which dispassionate analyses are rare.

The Ethiopian parliamentary elections of May 2005 were the most contested ever. Preceded by a relatively free and open public debate between the dominant party and the opposition parties, as well as by more widespread campaigning in the countryside than hitherto, they generated an atmosphere of hope and dynamism. But they ended in sharp disagreement, controversy, and massive repression of popular protest in the post-election phase. Opposition parties claimed to have won but to have been denied victory because of rigging, and when their demands for new elections in contested constituencies were rejected, they called for demonstrations.

A period of instability and violence began, leading to the killing of dozens of people and the arrest of tens of thousands of alleged opponents and protesters and the suppression of civil society groups. Political dialogue between the governing party and opposition forces, mediated by European Union (EU) diplomats, was aborted; concessions to the opposition, which had indeed won substantially, were refused. Political deadlock followed and disillusion came to reign in the mind of the public. ${ }^{9}$ In late October, the leading opposition party CUD boycotted entry into the new parliament and announced a round of peaceful demonstrations and boycotts, which were countered by a new round of violent suppression by police and Special Forces. As of early December 2005, the CUD opposition still refused to take up its new seats in parliament - and by then, its leaders were physically incapable of doing so because they were all in jail. Protests continued. The government chose to see all protests as a 'law-and-order' problem and took measures to forcefully suppress them.

The setback of this 'process of democratization', announced by the EPRDF regime after taking power in May 1991 and still publicly affirmed, can be explained with reference to the nature of elite rule, Ethiopian political tradition, the weaknesses of civil society, and the lack of a countervailing middle class in Ethiopia. In what follows, I briefly revisit Ethiopian political culture in the light of neo-patrimonial theory, thereby emphasizing the continued need to reconceptualize the analysis of politics in Ethiopia, away from the formal political science approaches predominating so far, towards a view of politics in more cultural terms, taking into account ethnic/kinship networks, local conceptions and psychologies of power, the role of ideology, and (informal) business interests.

9. See R. Crilly, 'Feeling is not good after Ethiopia vote', USA Today, 2 July $2005<$ http:// www.usatoday.com/news/world/2005-07-20-ethiopia_x.htm> (20 October 2005). 
Many analyses of Ethiopian politics after 1991 emphasized the formal political reforms ${ }^{10}$ and the new federal system and its constitution ${ }^{11}$ and discussed the parties and liberation movements, ${ }^{12}$ the two-chamber parliament, the reforms in the legal system, and so on. These formal institutions and actors are precarious and embedded in other power contexts, dependent on forceful personal action and informal power networks behind the façade. Donor-country diplomats, especially, are charmed by this formal façade of Ethiopian politics and always place high hopes in the promises offered by the political leadership. When asked about the political state of play in Ethiopia, they point to the improvements in the sphere of parties, the legal framework or the media, the reduced level of public violence, the absence of civil war, the relative scarcity of random killings and abductions of opponents, the prudent macro-economic policy, and the liberalization of the economy and the political system. In this, the despised Derg dictatorship (1974-91), and perhaps the disarray in neighbouring Somalia, is still the measure. This approach tends to underestimate the authoritarian patrimonialized system in place. This limits democratization and reform and, in effect, tends to perpetuate the rule of a party and an elite that cannot afford to relinquish hard-earned power. One can even historically understand this point: the ruling party - that emanated from the successful TPLF insurgent movement - came to power with the force of arms, its members sacrificing a lot during the insurgency (1975-91). Their political-economic stakes are now great. Many people in positions of power from the federal level in Addis Ababa to the k'ebele (local community) level are appointed because of loyalty to the party; they have income, privileges, and jobs to lose and will not voluntarily give them up, because unemployment, insecurity, or poverty is waiting. ${ }^{13}$ An old saying in Ethiopia is: 'He who does not "eat" while in power, will regret it when he is out'. This still holds. So next to substantial ideological differences and a conception of power as a cherished prize and as indivisible, there is a deep economic, if not survival, logic behind the political process in Ethiopia. The state resembles a

10. T.S. Lyons, 'Closing the transition: the May 1995 elections in Ethiopia', fournal of Modern African Studies 34, 1 (1996), pp. 121-42.

11. A.M. Abdullahi, 'Article 39 of the Ethiopian constitution on secession and self-determination: a panacea to the nationality question in Africa?', Verfassung und Recht in Übersee 31, 4 (1998), pp. 440-55; Kidane Mengisteab, 'Ethiopia's ethnic-based federalism: 10 years after', African Issues 19, 1-2 (2002), pp. 20-6.

12. S.F. Joireman, 'Opposition politics and ethnicity in Ethiopia: "we will all go down together" ', fournal of Modern African Studies 35, 3 (1997), pp. 387-407; Medhane Tadesse and J. Young, 'TPLF: reform or decline?', Review of African Political Economy 30, 97 (2003), pp. 389-403.

13. After May 1991, the EPRDF quickly moved to take over key sectors of the Ethiopian economy. This was a quite successful operation. Large business conglomerates are now headed by prominent party members or their associates/relatives. A first - anonymous report that inventoried the take-over in detail was 'Ethiopian Non-Governmental Businesses, A Preliminary Survey' (Addis Ababa, 1996, unpublished, 56 pp.). The new patronage networks draw heavy criticism from the disadvantaged non-party-affiliated business people. 
domain of personalized power and resource competition through the instrumentalization of vertical loyalties among special, strategic constituencies. Resource competition, although not explaining all, goes a long way in accounting for Ethiopia's exclusivist and conflictual political dynamics. ${ }^{14} \mathrm{It}$ must be said that the TPLF-EPRDF has done much to realize economic reforms in Ethiopia but did not complete its political agenda, ${ }^{15}$ which included entrenching power and transforming Ethiopian political culture (towards ethnic politics), social structure (neutralization of interest groups based on private business, or 'narrow nationalist' regional identities), and public mentalities (eliminating, or at least containing, the influence of religion in public life, balancing and co-opting Christianity and Islam, and inculcating ethnic consciousness).

Although the 2005 elections are only one ephemeral moment in Ethiopia's political development, what happened on this occasion is illustrative of certain relatively unchanging structures and notions in Ethiopian politics. There are two theoretical points here: first, a focus on formal politics is misleading. In Ethiopia, where institutional reforms and a process of political liberalization began in earnest after 1991, the vital political decisions are made in the informal sphere, behind the façade, in circles and networks of a neo-patrimonialist nature, impervious to what institutions like a parliament or a high court say. Although one can fault the neo-patrimonialist paradigm for its somewhat biased and limited view on the political process in African states (cf. Therkildsen 2005 for a recent critique), its core idea - following Médard (1996) - of the combination of semi-bureaucratic and patrimonial logics in one personalized political system is still a fruitful point of departure, especially in a country where ethnic and cultural solidarities are important, even formative, to the cohesiveness of the political elite. Second, Ethiopian political struggles and power politics reflect the peculiarities of social structure, notably the lack of a strong, economically rooted middle class and a corresponding, independent, civil society that can be a countervailing force to the dominant party or government. Although a civil society has been emerging slowly in the past 15 years, it was dealt a blow by the current regime before and after the May 2005 elections (A core issue is the perpetual onslaught on property rights, of which no one can ever be legally sure). This seems to support Gill's analysis, ${ }^{16}$ which emphasizes the vital role that civil society organizations, next to

14. A recent study by two Ethiopian researchers has underlined that Ethiopia is a significantly 'conflict-prone' country, where '... new regimes have failed to learn the lessons of their predecessors': Alemayehu Geda and Befekadu Degefe, 'Conflict, post-conflict and economic performance in Ethiopia', in A.K. Fosu and P. Collier (eds), Post-Conflict Economies in Africa (Palgrave-Macmillan, New York, 2005), p. 138.

15. For a basic statement of this, see 'Our revolutionary goals and the next steps', Amharic document for TPLF members, June 1993 [translated version in Ethiopian Register 3, 6 (1993), pp. 20-9].

16. Gill, Dynamics of Democratization. 
elites and institutional structures, must play in a successful democratic transition. In the Ethiopian countryside, there are even fewer power groups or strata than in the towns and cities, because of state ownership of all land, periodically redistributed to uproot possible interest groups or entrepreneurs and keep the peasantry dependent.

\section{Context and background}

Ethiopia is an important African country, with a relatively strong and functional administrative machinery and a well-organized army. It is poor and economically underdeveloped but still the major player in the Horn of Africa, with a population of some 77 million people ${ }^{17}$ - more than that of its four Horn neighbours (Sudan, Eritrea, Somalia, and Djibouti) combined. Political and regime stability is a major concern both among donor countries (mainly the United States, EU, Japan, and China) and among the EPRDF elite in the country itself. Ethiopia is a recipient of comparatively large sums of donor funds. In this context, the current leadership of Ethiopia has effectively tuned in to the donor discourse of liberalization and democratization.

The ruling party EPRDF took power in 1991 amidst a surge of relief and cautious optimism after the civil war and the devastating Derg regime. To some observers, notably donor-affiliated ones, it appeared puzzling why, despite the promises and the new start, the Ethiopian regime did not, after 15 years in power, make a decisive breakthrough to a democratic politics based on compromise strategies and a wide national agenda. This approach ignores the history and nature of the insurgent movement TPLF/ EPRDF that came to power via the familiar route of military action, based on forceful mobilization of a rural constituency and a rather sectarian ideology. It has not been successful in consolidating the initial momentum and establishing nationwide acceptance. In the political system as reshaped after 1991, public trust is lacking. This 'commodity', facilitating political communication and establishing a measure of predictability and a will to overcome differences in a shared political arena, is a prerequisite in the complex arena of Ethiopian politics. In the 2005 election period, the lack of trust - in the government, the fairness of the counting, the political negotiation process, national issue politics, and parts of the opposition has had serious consequences for politics in general but in particular for the government and the EPRDF. Distrust and cynicism, although engrained, were ignored by the ruling party before the elections because of a wrong assessment of its own political record, its underestimation of the

17. United Nations Family Planning Association press release, 13 October 2005. The current annual growth rate of at least 2.4 percent is high and undermines environmental recovery, economic growth, and the realization of the Millennium Development Goals. 
desire for political space among the population, and the party's biased and generally poor economic achievements, notably in the rural areas. The party's own power base, buttressed by political-economic and military clout, was in the rural north, in the Tigray trading class, and among peasants, smaller ethnic minorities, and elites from various ethnic groups coopted into a parallel structure of ethnic parties in all regions. This constituency was not expected to show dissent, but it did. Notably the peasants of the northern and western countryside and ethnic minorities started to vote for alternative parties, despite the administrative and economic hold that the ruling party was exercising.

As noted above, the 'economics of scarcity' that underlies much of African politics is an explanatory element accounting for the reproduction of neopatrimonial tendencies. Also in Ethiopia, politics is a game where the stakes are high ${ }^{18}$ and where the constituencies of the power holders insist on their privileged access to resources and thus reject change towards more equitable structures. Political power in the country is closely tied to material and economic interests. In the imperial era, the land-holding class was the basis of power, and the inequalities and economic stagnation in that system contributed to the downfall of the emperor in 1974. The subsequent Derg regime, a Marxist junta led by army officers, nationalized all land, abolished the imperial system, and followed a socialist development model. But because of its dogmatic form of state socialism, repressive domestic policy, and the crippling war with Eritrean and other rebel movements, it did not succeed in achieving legitimacy, stability, or economic growth. The ethno-regional insurgency of the TPLF-EPRDF (1975-91), based in the northern Tigray region, toppled this regime in 1991, in combination with the Eritrean resistance forces (Eritrean People's Liberation Front). The EPRDF elite fundamentally restructured the Ethiopian state, redefined Ethiopia's relation with independent Eritrea, and co-opted the economy by bringing it largely under its own control. Despite liberalization and economic growth in the formal sector, the problems of food insecurity, public health, unemployment, urban poverty, disrespect of human rights, and ethnic tensions were not resolved, and public dissatisfaction mounted. This was despite the post-1991 agenda of democratizing the country, first and foremost by giving ethno-linguistic groups more recognition and rights and by working towards a parliamentary democracy with periodic elections and a reformed judicial structure. The party leadership, however, seems not prepared to implement it to the end and follows its own agenda. ${ }^{19} \mathrm{~A}$ study of the electoral process is crucial in revealing the problems of Ethiopian politics and its relapse into centralist authoritarian tendencies.

18. Médard, 'Patrimonialism, neo-patrimonialism', p. 87.

19. This agenda is contained, for instance, in Abyotawi Demokrasi ('Revolutionary Democracy'), an about 700-page internal EPRDF ideological document, Addis Ababa 2001. 


\section{Electoral preludes}

The Ethiopian political process before the elections, observed and monitored with high expectations by the donor-country community, showed an unprecedented openness and dynamism before the voting day, 15 May 2005. Campaigning and publicity were better than in any preceding election. The ruling party and the prime minister had reiterated their commitment to further democratizing the country, and this generated incremental expectations of change and power sharing. Before the election, important debates were held on state television and in the written media, and preelection negotiations between the contenders had discussed procedures and campaigning. There was some doubt whether the new space for campaigning was a policy to which the regime was genuinely committed, or whether it was primarily a gesture to answer donor-country pressure. It also has to be noted that in these various debates and exchanges in the media and in public meetings, no fundamental agreement on the core political issues, or even on the basis of the Ethiopian state and its institutions, was reached: deep divisions remained. ${ }^{20}$ There were also many reports of disturbances to election meetings and of intimidation of and violence against opposition members in the countryside, ${ }^{21}$ where several people were killed.

A remarkable fact in $2004-5$ was the quick growth to political prominence and organizational skills of the new opposition parties - mainly the Coalition for Unity and Democracy (CUD) - in Amharic Qinijit - and the United Ethiopian Democratic Forces (UEDF) - in Amharic Hibrät. The CUD was led by people from the urban middle class like Berhanu Nega, a well-known economist, Mesfin Wolde-Mariam, an influential, retired professor, Lidetu Ayalew, a politician of the young generation, Hailu Shawel, a veteran businessman and former vice-minister, and Yaqob Haile-Mariam, a respected international legal expert. The UEDF was led by the veteran leaders and university lecturers Beyene P'etros and Merera Gudina.

The social basis of the two large opposition parties was very diverse. The UEDF emerged from a coalition of largely ethnic-based opposition groups (SEPDC, ONC, ARDUF, etc.) that had emerged after 1991 in the south and west of the country, representing, for example, Hadiya, Kambata, Gurage, Oromo, Gamo and many smaller groups, and members of these groups in the urban areas. It also includes parties with a largely diaspora following. The CUD is a coalition of four parties with a largely urban and

20. See Yitzhak Kiflegzie, 'Bereket's harassment as "political” debate', The Reporter (Addis Ababa), 19 March 2005.

21. See reports in the local Ethiopian press: Dagim-Wonch'if, 29 March 2005; T'obbia, 14 April 2005; T'omar, 13 April 2005; Reporter, 17 April 2005; Seife-Näbälbal, 21 April 2005. Sea also the Ethiopian Human Rights Council, 80th Special Report, 19 October 2004. 
business-class constituency - civil servants, teachers, professionals, university lecturers, traders, shopkeepers, and others, but with a growing following among ordinary people and in rural areas in central, western, and northern Ethiopia. CUD's growth within one year of its merger in 2004 is to be explained, next to the appeal of its leaders, by the profound disillusion with EPRDF among the non-party-affiliated trading class and the peasantry in the highlands. ${ }^{22}$ Compared to the UEDF, which is more ethnic-particularistic although committed to an agenda giving space to all ethnic groups within the state, the CUD is more nationally oriented, adhering to a pan-ethnic programme aimed at issue politics and for liberalized, equitable economic development.

In general, the new opposition parties reflected the public impatience and dissatisfaction with the government's record and people's clamour for change. ${ }^{23}$ Although the government cannot be blamed for all the problems facing the country, a general attitude of malaise and often cynicism was notable among the wider public regarding the economy (agricultural stagnation, food insecurity, corruption, and nepotism), health care (growing AIDS and TB infection rates and shabby state of the health infrastructure), foreign policy (especially towards Eritrea), and the perceived lack of government transparency and policy predictability in general. The opposition parties stressed an alternative, national, pan-regionalist, and pan-religious agenda, and - especially the CUD - expressed scepticism about the ethnic-federalist model, the land policy, the Eritrea question, and economic policies.

Although lauded by observers as relatively open and competitive, the preelection period, as mentioned above, was not free of violence and intimidation. The atmosphere was always very tense under the surface. In an Ethiopian TV address on 5 May 2005, Ethiopia's prime minister heightened the tension with a speech saying that the opposition was 'fomenting ethnic hatred that could erupt into violence'. ${ }^{24}$ He raised the image of the violent Rwandan Interahamwe militia as something that the opposition might emulate. ${ }^{25}$ This was a new element, because up to that point there had been

22. Some observers were quick to label the CUD as 'Amhara chauvinists', an incorrect and rather mischievous qualification, reflecting the wish to ethnicize Ethiopian politics. No doubt some entered the CUD as representatives of the Amhara/Amharic-speaking people, but the party's political agenda was national, not ethnic.

23. See, for instance, a report of PINR (an independent US-based research institution), 'Intelligence Brief: Ethiopia', PINR, 25 October $2005<$ http://www.pinr.com/report.php?ac= view_report\&report_id=387\&language_id=1>.

24. See 'Ethiopia - Zenawi accuses opposition of agitating for poll violence', AFP, 6 May 2005 [Also in the Sudan Tribune: <http://www.sudantribune.com/article.php3?id_article=9432> (23 October 2005)].

25. A reference called 'ridiculous' in the article 'Ethiopia: a taste of democracy', The Economist, 19 May 2005 <http://www.economist.com/displaystory.cfm?story_id=3996217> (15 October 2005). 
no talk in the campaign of ethnicity as such, despite the fact that all parties had some major ethno-regional constituency from which they drew support.

In April 2005, the National Electoral Board of Ethiopia (NEBE) had disallowed some 30 local non-governmental organizations to act as observers. An order of the Ethiopian High Court later reversed the decision, but by then it was too late for them to enter the observation process. As these local NGOs knew the situation on the ground very well and could have made a major contribution; their absence was a significant setback for the election process.

\section{Elections and their setting}

The 15 May 2005 elections were the third multiparty parliamentary elections since 1991 and were arguably the most significant and eventful round of voting in Ethiopia so far. ${ }^{26}$ Registration was very high, and voter turnout was about 80 to 90 percent. People felt that change was possible, and they were prepared to stand in line for many hours. This in itself was a big gain for democracy in the country. Previous occasions in 1995 and $2000^{27}$ were much more controlled by the ruling party EPRDF, to such an extent that in those elections 'free-and-fair' voting could not be fully realized.

Preceded by months of argument and contestation, the final results of the count (including the delayed one from the Somali region) were published on 5 September 2005. But already on 17 May, Prime Minister Meles Zenawi announced an 'overwhelming victory' for his party, the EPRDF: a remarkable observation to make two days after election day with little counting done. ${ }^{28}$ But indeed, in the end the dominant party was again confirmed in power. The EPRDF officially gained 371 seats (or 67.8 percent of the vote), as against 174 for the combined opposition parties, from a total of 547 contested seats in the parliament. ${ }^{29}$ The UEDF won 52 and the CUD 109. These two opposition parties conquered the seats in virtually all towns and urban areas, most notably in Addis Ababa.

\footnotetext{
26. There were parallel elections for the regional houses of parliament. For results, see the National Electoral Board of Ethiopia website <http://www.electionsethiopia.org/PDF/results/ Regional\%20Council\%20Summary.pdf> (23 September 2005). In these regional elections, the dominant party EPRDF also carried most of the seats. In Tigray, the seats were all for the TPLF. In the Addis Ababa region, the opposition party 'Qinijit' (CUD) won all 138 seats except one. Because of the unresolved post-election crisis, the CUD has not yet taken over the city's administration as of January 2006. They are now prevented from doing so, because in the November 2005 crisis the entire leadership was thrown in jail. It is possible that the government will, by procedural changes and stalling, block the CUD take-over of the capital's administration.

27. S. Pausewang, K. Tronvoll, and L. Aalen (eds), Ethiopia since the Derg: A decade of democratic pretension and performance (Zed Press, London, 2002).

28. See the Ethiopian weekly The Reporter, 18 May 2005.

29. See National Electoral Board of Ethiopia website <http://www.electionsethiopia.org/ Index.html> (23 September 2005). The final results were released some 3 and a half months after the election date (5 September 2005).
} 
The result showed that the opposition parties made great gains, going from 12 members in the previous parliament to 174 now. Despite their successes, the opposition parties were dissatisfied and already during the counting process appealed for re-votes in many constituencies where irregularities had allegedly occurred. They were supported in this assessment by most international observers. The ruling party EPRDF - which had never any doubt about winning, and in fact could not imagine losing - got a great scare during the initial vote-counting process and tried to stem the tide of loss. The counting was quite tortuous and delayed by many weeks. The EU Observer Mission had already expressed its worry about the counting process in a statement 24 May:

The European Union Election Observation Mission regrets the way in which the counting of the votes at the constituency level is being conducted as well as the way in which the release of results is being handled by the electoral authorities, the government and the political parties, especially the EPRDF.

The immediate post-election period was thus one of enormous controversy and acrimonious debate between the protagonists and of non-transparent manipulation with the vote counting (Smidt, W. G. C., 'Parlamentswahlen in Äthiopien', Afrika Spektrum 40, 2 (2005), pp. 31930). Also the complaints investigation supervised by the governmentappointed NEBE was highly contested. The opposition accused the NEBE of being biased towards the ruling party. Not only in Ethiopia itself, but also in the Ethiopian diaspora communities, emotions ran high and fierce accusations were traded on a daily basis in numerous website discussions, which contributed to polarization.

Based on observer reports and oral information on incidents from voters, it is no doubt the case that the elections were not perfect and that a large number of constituencies had no fair electoral process. Not only were the reports of local people complaining about military, cadre, and police intimidation too numerous to discount, but also foreign observers had criticism, especially the EU (see below, p. 15). As to the vote-counting process, opposition and EPRDF disputed 299 constituencies to the NEBE as disputed. ${ }^{30}$ But after the complaints review, only 39 were accorded a rerun. The freeness and fairness of these re-elections could not be assessed. Surprisingly, several leading but quite unpopular regime members defeated in the first election round were reinstated after re-elections in their constituency. Among them were former OPDO chief Kuma Demeqsa, Defence Minister Abadula Gemeda, Information Minister Bereket Simon, and OPDO chairman Juneddin Saddo. Reports from these re-elections mention

30. Quite a number of the constituencies disputed by the CUD (the large majority of them) seemed to have been contested on less than convincing grounds. EPRDF disputed 70 of the 299 seats. 
intimidation of voters and the 'disappearance' of ballot boxes on their way to the counting office. Many reruns of the vote were therefore even more controversial than the first round. One reason, apart from intimidation of rural people, is that both voting and vote counting require supervision by a strictly neutral electoral board and observers, but indications were that NEBE was not immune to government interference.

In October 2005, Zenawi was returned, with a trusted group of ministers and advisors (state ministers), and Ethiopia entered another five years of EPRDF rule. ${ }^{31}$ The outgoing government quickly changed some parliamentary rules to minimize the impact of the opposition in the parliament, should they take up their seats. The most important change was a rule that required 51 percent of the parliamentarians to support an initiative before it could appear on the House's agenda. Previously, it was 20 percent. $^{32}$ Also introduced was a rule to remove from parliament MPs using 'insulting and defamatory language'.

\section{Backlash: repressive measures and political closure}

As the vote counting unfolded from 15 May onwards and the opposition appeared to have performed well, even claiming prematurely to have won the elections, the ruling party took measures to calm the situation and reassert control. A ban on public demonstrations was declared for a month after the voting day, a state media campaign was started to accuse the opposition of disloyalty, and journalists were arrested. In what seemed to be a campaign of punishment, in the countryside ruling party politicians, cadres and police started harassing perceived opposition opponents, of which thousands were arrested, ${ }^{33}$ and reportedly at least one elected candidate for the parliament was shot and killed in unclear circumstances. ${ }^{34}$

31. During one interview with the BBC's Steven Sackur, in the programme 'Hard Talk', 4 July 2005 <http://news.bbc.co.uk/1/hi/programmes/hardtalk/4649373.stm>, Prime Minister Meles Zenawi had said, in response to a question on how long he would serve: 'That's up to my party to decide' and '... people have to stay as long as the people want them to stay, and do so through freely-contested elections. The decision has to be that of the people in the final analysis'.

32. It also changed rules for city revenue collection (e.g. from public transport) and budget support for the Addis Ababa region, to be governed by the opposition CUD (Oxford Analytica report, 'Ethiopia: boycott, protest threats heighten insecurity', 23 September 2005). This hampers the economic possibilities of the new administration - if it ever materializes - and will in due course have residents shift the blame to the new city government.

33. See 'Thousands arrested across Ethiopia in post-election crackdown', Washington Post, 16 June $2005<$ http://www.washingtonpost.com/wp-dyn/content/article/2005/06/15/AR20050 61502416.html> (24 July 2005).

34. This was Tesfaye Adane Gara in Arsi Neghele. His case is described in a documentary Australian radio ('Date line') <http://news.sbs.com.au/dateline/index.php?page $=$ transcript $\&$ dte $=2005-08-24 \&$ headlineid=1013> (25 October 2005). 
In early June, Addis Ababa University students were the first to defy the ban on demonstrations and staged a spontaneous sit-in strike on Monday, 4 June, to protest the arrest of students suspected of being CUD party supporters in the dormitories. They then protested 'the stealing of the elections' by the ruling party. The federal police inflicted violence on this on-campus protest, and next day when arrested students were driven past the Kotebe Teachers' College in army trucks, protests also started there and police opened fire. One female student was killed. ${ }^{35}$ In the next two days, taxi drivers began a strike, drawing severe threats and beatings from government forces, and students in Bahir Dar, Awasa, and Ambo regional universities also raised their voice. On Wednesday 8 June, street demonstrations by students, high-school children, and street youths began in Addis Ababa. The government gave orders to suppress it 'at any cost', and special armed units popularly called the $A g^{\prime} a z i$ (originally a special army division), consisting predominantly of Tigrayan soldiers who, according to witnesses, could or would not speak Amharic, ${ }^{36}$ did not communicate with protesters or bystanders, and instantly acted aggressively to suppress any protest. About 46 people - probably more - were killed, hundreds wounded, and more than 350 arrested. A high school near Mexico Square in the capital was emptied of its protesting pupils who were carried off in army trucks. The government also put opposition leaders under house arrest, harassed others, and started some court cases and media campaigns against them.

Opposition parties and the ruling party had signed an EU-mediated pact on 9 June to abide by the law, refrain from escalation, and appeal to the NEBE to address complaints about voting irregularities. But this agreement did not have a cooling effect and was not followed up. Distrust and irritation grew, with the government showing no signs of compromise or confidence building, and the opposition becoming more adamant in demanding redress, no doubt overstating their case.

The opposition parties, especially the largest one, CUD, gave out numerous press statements in the subsequent weeks, accusing the ruling party of election fraud, stealing the victory and indiscriminate repression, and demanded new elections. They also called for peaceful public protests. But a big demonstration announced for 2 October 2005 on the central Mäsqäl Square of Addis Ababa was cancelled because the indications were that the government and its riot police would provoke violence, and people might be killed in a massive confrontation.

Some observers spoke of a general tendency of 'criminalizing' opposition members and sympathizers by government media. The demonstration of the opposition on 2 October had been labelled by the government leaders

35. A first detailed report on the disturbances was Statement no. 84 (15 July 2005) of the Ethiopian Human Rights Council (Addis Ababa).

36. The language predominantly spoken in the capital. 
as a 'serious crime', the opposition was repeatedly accused of 'plotting to overthrow the government', and people in the possession of arms - even guards of opposition party branch offices - were declared suspects. ${ }^{37}$ There was, however, no substance in the government allegations of any armed rebellion prepared by opposition groups - the latter had no arms or armed wing, and none of their statements could be interpreted as being a call to the use of violence. Violent struggle was, however, proclaimed by non-legal opposition groups like the OLF, OLNF, and some others, operating in peripheral areas (Ogaden, Gambela, Western Oromiya, and Afar) and drawing support from discontented youngsters and local ethnic groups affected by earlier state repression or neglect.

\section{Observers and donors: international responses}

The 'international community' - mainly the EU and United States - was important not only as an invited observer at the 2005 elections but also as the general environment or reference point, for the regime to take into account. For economic and other reasons, Ethiopia wants to have good relations with the donor community - and the regime kept up the rhetorical and policy commitment to democratization and economic liberalization. There is normative pressure on aid-dependent governments in the developing world to implement the agenda of internationally agreed democratic ideas, good governance, rule-of-law principles, transparency, and accountability (also proclaimed by the United Nations). These concepts are not only 'donor speak' but are also widely shared by the ordinary population in those countries.

Some 300 international observers were present during the elections. The most important observer reports were those from the EU and the United States. ${ }^{38}$ But the African Union (AU) was also there. Its report ${ }^{39}$ was rather insignificant, based on a very small sample of observers, and superficial. It did not reflect reality and was in line with the customary AU mild responses to the abuse of power (as in the Zimbabwe case and the Darfur issue). The AU did not seem overly concerned - despite its lack of criticism on election flaws being against the letter and spirit of the NEPAD peer review mechanism.

The EU delegation, however, gave a well-founded critical evaluation of the elections, based on a principled and detailed analysis of the entire electoral

37. See 'Ethiopia arrests 43 opposition members before rally', Reuters, 26 September 2005 <http://www.alertnet.org/thenews/newsdesk/L26392186.htm> (23 October 2005).

38. The other large powers in the world community - China and Russia - and Arab countries in the wider region kept quiet, in conformity with their lack of interest in the furthering of democratic ideals and rule of law in the northeast African sub-region.

39. See AU Press release 45/2005 (of 10 August 2005), 'Statement of the African Union on the Ethiopian Legislative Elections held on Sunday', 15 May $2005<$ http://www.africaunion.org/home/Welcome.htm>. 
process. Praise was given for the preliminary phase, the relatively free debate and campaigning, the technical preparations, and the voting process, but it was critical about the voting day practices and the selective intimidation of voters and opposition candidates. ${ }^{40} \mathrm{EU}$ observers did not see the voting process in the large majority of the rural constituencies. They nevertheless did a commendable job, showing that the EU took its role of observer seriously. The response of Ethiopia's prime minister to the EU's preliminary report (in the form of a very long letter to the state newspaper Ethiopian Herald, 29-31 August 2005) was generally seen as disproportionate and embarrassing, containing a blanket rejection of any criticism and an ad hominem attack on the EU mission and its chairperson Ms Ana Gomes, a Portuguese Euro-parliamentarian.

The US government response was also critical but did not reject the election results outright. ${ }^{41}$ In a cautious, non-committal statement, it criticized the 'irregularities' of the electoral process but called for peaceful negotiations on the outstanding issues. Later, it urged the opposition parties to just take up their seats in parliament. Although several observer groups from the United States were allowed to attend the elections, three groups were sent back in March. ${ }^{42}$ Only the Carter Center group remained. They gave a statement on 15 September $2005 .{ }^{43}$ It concluded that:

The elections process demonstrated significant advances in Ethiopia's democratization process, including most importantly the introduction of a more competitive electoral process, which could potentially result in a pluralistic, multiparty political system.

Elsewhere:

However, a considerable number of the constituency results based on the CRB and CIP processes are problematic and lack credibility. Within the universe of seats impacted by the complaints process, many of these cases lacked sufficient evidence to warrant challenging the result. However, serious problems were found in parts of the CRB [Complaints Review Board] process and in a considerable number of the CIPs [Complaints Investigation Panels]. ${ }^{44}$ In addition, there were problems in some of the re-election constituencies.

40. This report (of 25 August 2005) is available at the website $<$ http://www.et-eueom.org $>$ (20 October 2005).

41. State Department press statement, 1 September 2005. Also their press statement of 16 September $2005<$ http://www.state.gov/r/pa/prs/ps/2005/53355.htm>. It said: 'Because reported election irregularities raised concerns about transparency, we will work with the international community and the Ethiopian government and parties to strengthen the electoral process'. But no results were achieved on this score.

42. These were the National Democratic Institute (NDI), the International Republican Institute (IRI), and the International Foundation for Electoral Systems (IFES), allegedly 'operating illegally in the country'.

43. See <http://www.cartercenter.org/documents/2199.pdf>.

44. Both instituted ad hoc by the National Electoral Board of Ethiopia. 
So again, this was a mixed message satisfying both the ruling party and the opposition views and was based on observation across the country on only a limited scale (with 50 observers). Initial US government statements did not show that in the context of their wider, and partly misconceived, geo-political interests they took the Ethiopian political crisis very seriously, but a more critical tone emerged in January 2006.

In the post-election controversies about the results and the complaints process, the Ambassadors' Donor Group and the EU (with delegation head Timothy Clarke) actively tried to mediate between ruling party and opposition. ${ }^{45}$ The United States and other countries appealed for calm and for the opposition to enter the parliamentary process. On 20 June 2005, a group of 13 prominent US members of Congress issued a letter to the Ethiopian prime minister objecting to anti-demonstrator violence and urging restraint. ${ }^{46}$ The EU was active in attempting negotiated solutions but lost patience with the heavy-handed approach of the government and the intransigence of the opposition. On 13 October 2005, the European parliament gave out a press statement urging an end to government persecution of the Ethiopian opposition and the release of the thousands of demonstrators. The statement concluded with a call to step up humanitarian policy and to possibly readjust the European Commission's humanitarian aid to Ethiopia.

It seemed that the Ethiopian government could no longer count on unconditional support from the EU, although as usual the EU leadership had been hesitant in May-June 2005 to support its field observer mission reports and act on the recommendations. Behind the diplomatic façades, however, the dissatisfaction with the current Ethiopian regime was substantial. In January 2006, Great Britain announced that it would cut all its aid ( $\$ 88$ million) to the government.

Even the usually 'non-political' World Bank, which had been silent since 1991 because of reasonable formal economic growth rates of between 2 and 8 percent annually, gave warnings of possible aid reduction and a refocusing of programmes. In a November 2005 interview, the Bank country representative in Ethiopia expressed doubts about the course that the Ethiopian government was taking, hinting that it endangered governance, stability, and macro-economic achievements so far. ${ }^{47}$ Although this World Bank spokesman perhaps painted a somewhat too positive picture of the actual economic progress achieved, his words nevertheless illustrated that,

45. See also the interview with Clarke in the Ethiopian weekly Capital, 15 November 2005, expressing his dismay at the violent turn of events.

46. Posted on many websites, among them: <http://www.ethiopiafirst.com/news2005/Jan/ Congress-Letter-June20.pdf $>$. Although their concern was justified, this letter suffered from some exaggeration and inaccuracies.

47. IRIN interview with Ishac Diwan, 18 November $2005<$ http://www.irinnews.org/ report.asp?ReportID=50171\&SelectRegion=Horn_of_Africa $>$ (21 November 2005). 
even in the eyes of 'non-political' institutions, the turn towards authoritarian politics was seriously at cross-purposes with equitable economic development and enhancement of well-being (including poverty reduction) of the population at large, things already felt by the Ethiopian masses for several years. ${ }^{48}$ In December 2005, the donor consortium (EU and World Bank, but not the US) announced it was withholding $\$ 374$ million in budget support to Ethiopia.

\section{Authoritarian resurgence? The 'business as usual' approach of the government}

The negotiations between the EPRDF government and opposition leaders in October were inconclusive, court appeals were dragging on, and the enmity increased, with aggressive and defiant exchanges between the spokesmen of both sides. ${ }^{49}$ The CUD opposition increased the tension with a series of statements on boycotts, preconditions for entry into parliament, and calls for re-elections, mass demonstrations, and stay-at-home strikes; while the government added accusations against the opposition of ethnic polarization, treason, illegal arms possession among opposition members, and incitement to violence by the opposition. ${ }^{50}$ These latter accusations lacked a credible basis in fact. True is that the opposition had been showing increasing signs of intransigence and might have overestimated its powers (cf. Joireman 1997 for a first study of the problems of the opposition). Even though it might have close to a majority of the population behind it, it was, in the current political conditions, not quite feasible for the opposition parties UEDF and CUD to take over power.

The ruling party's ignoring of the appeals of the opposition for recounts or re-voting of all disputed constituencies (discussed above) may have been the crucial mistake. A huge opportunity was lost, as so often in modern Ethiopian history. If a quiet and credible reassessment, with observers and transparent vote counting, of the contested constituencies would have been made - and these surely would not all have gone to the opposition - then the outbreak of protests, the boycotts, and the violent repression would probably have been avoided. This reassessment would have been a facesaving exercise that could have both enhanced the legitimacy of the

48. However, Ethiopia's recent economic policies have not all been a dismal failure; there were many new initiatives and significant GDP growth. See for an interesting opinion piece: 'Our material poverty has little to do with the resistance against Meles \& Co.', by Bezuayehu Kegerji (pseudonym), on a critical Ethiopian diaspora website <http://www.ethiomedia.com/ fastpress/message_to_our_donors.html> (15 November 2005).

49. Prime Minister Meles Zenawi's interview of 25 September 2005 was marked by quite bellicose language <http://www.waltainfo.com/EnNews/2005/Sep/25Sep05/Sep25e2.htm> (24 October 2005).

50. See 'Ethiopia: opposition party calls for consumer boycott', IRIN (UN) < http://www. irinnews.org/report.asp?ReportID $=49872 \&$ SelectRegion=Horn_of_Africa\&SelectCountry= ETHIOPIA> (1 November 2005). 
government and enlarged the number of opposition seats. But the EPRDF government, fearing the momentum of change, ignored all calls for further negotiation or a government of national unity, convened the new parliament on 5 October, and introduced the new ministerial team. Most opposition members boycotted the parliament on that day, prompting the government to lift their parliamentary immunity. Strictly speaking, this was unconstitutional because this measure could only be taken when parliamentarians committed crimes.

The opposition, in the face of government refusal, became more rigid in its rejection of the legitimacy of the elections and was not prepared to enter parliament, except for some CUD members, most of the UEDF, the two smaller parties (13 seats), and one independent candidate. The opposition faced a dilemma: sticking to principles - rejecting a seriously flawed election - or compromising and at least securing some voice for the opposition in an EPRDF-dominated and -controlled parliament. Admittedly, the ruling party - by its intimidating tactics and its changing parliamentary rules, notably the new, higher quorum for bringing agenda items - had made it difficult for opposition to have any influence. Since October 2005, the two main opposition parties, CUD and UEDF, were also plagued by internal divisions and could not formulate a coherent leadership or a unified policy. Ethiopian diaspora groups started expressing disappointment with opposition tactics during the November crisis. An additional problem was the use of 'moles', apparently by the government, to split the opposition parties into two. ${ }^{51}$ This appears to have worked with the Oromo National Congress (ONC), a part of the opposition UEDF party: the ONC leader Merera Gudina was replaced by an unknown opponent, Tolossa Tesfaye, after he was recognized by the NEBE and later by a court decision as the legal chairman. ${ }^{52}$

The government thus moved from stalemate to 'business as usual', ignoring public discontent and the need for compromise. It kept up repressive measures on a massive scale, in the towns and especially in the countryside. Under the guise of maintaining public order, it also became bolder in verbally attacking and physically harassing the opposition, especially the

51. This had also happened with the first pan-ethnic opposition movement, National Democratic Union (NDU) in 1993-94, which only survived for a few years before withering away. 52. Despite a large majority of ONC MPs still supporting Dr Merera. See 'A shake-up of the ONC', The Reporter <http:/www.ethiopianreporter.com/modules.php?name=News\& file $=$ article\&sid $=1113>$. Cf. for the political background, the interview of ONC chairman Merera Gudina with The Reporter <http://www.ethiopianreporter.com/modules.php?name= News\&file $=$ article\&sid $=1132>(26$ November 2005$)$. The UEDF also had internal problems because of the great role diaspora groups played in this party. For example, on 24 October 2005 , the two UEDF leaders were 'dismissed' by the (diaspora-dominated) executive committee of their party because of the committee's rejection of the decision to take up their seats in the new, contested, Ethiopian parliament. To dismiss these two prestigious and at that point indispensable leaders was a sign of immaturity. 
CUD and its presumed constituency. On 28 October 2005, security forces surrounded and beat up a CUD leadership meeting, also harassing journalists and two Dutch diplomats who came to the scene. On 31 October 2005, a peaceful car-honking protest was called, and it immediately led to arrests and beatings of taxi drivers and other motorists by government troops. This was probably the start of the new cycle of violence.

In subsequent weeks, starting 1 November, government forces acted to suppress spreading popular protests in Addis Ababa, killing at least 40-50 people and wounding hundreds of others. In weeks of unrest elsewhere, for example in provincial capitals and towns, dozens more demonstrators were killed. A massive clampdown on the independent press and several civil society organizations followed, with many journalists going into hiding. The government equally accused journalists from the Amharic programmes of the Voice of America and Deutsche Welle and, in January 2006, expelled the British Associated Press (AP) correspondent. The top CUD leadership was also arrested. In November-December 2005, government forces, in a countrywide sweep also covering the rural areas, ${ }^{53}$ arrested an estimated 30 to 40,000 people, many of them taken in trucks to far-off prisons (Zeway and Shewa-Robit) and remote, ill-equipped camps (Bir Sheleqo and Didessa). By mid-January 2006, 11,200 people were released, but the majority were still held, and reports about rampant abuse and deaths inside these camps were too consistent to ignore. ${ }^{54}$ In December 2005, the government charged the imprisoned CUD leadership and other people, including former Ethiopians living in the diaspora in Europe and the United States, with 'treason', a rather exaggerated and premature charge. It was later even augmented with 'genocide'. ${ }^{55}$ Although any credible evidence for such charges was lacking, those in custody were repeatedly denied bail by the court. The people arrested included respected lawyers, academics, NGO people, and other public figures. The repressive approach followed was further evidence of the assault on civil society and on the emerging, nonparty allied middle class as represented notably by the CUD. But it was a risky policy of over-reaction, which far from restoring order and authority continued to lose the government party support both domestically and internationally. It was the start of a longer phase of tension and instability. Not to be neglected are the psychological effects of the crisis: malaise, fear,

53. See Human Rights Watch statement, 'Ethiopia: hidden crackdown in rural areas', 13 January 2006.

54. See 'Democratic dawn in Ethiopia fades as abuses come to light', The Observer, 4 December 2005. Cf. also the documentary on Britain's Channel 4 of November 2005 $<$ http://www.channel4.com/player/playerwindow.html?id=1310\&vert=news $>$ (28 December 2005). Information from two former prisoners (Addis Ababa, 30 January 2006) from Didessa revealed that many prisoners had died because of disease and snakebites, whereas others were killed by hyenas and lions after escaping.

55. See 'Ethiopia charges opposition members with genocide', Reuters, 21 December 2005 $<$ http://www.alertnet.org/thenews/newsdesk/L2111222.htm> (25 December 2005). 
and cynicism among the public, perceiving politics again as dangerous business and as a closed elite affair. ${ }^{56}$ This included the deep shock about the police and army people prepared to use indiscriminate force against their countrymen. Trust in the political process and system of governance thus reached its lowest ebb. Notable since December 2005 is the involvement of high-school pupils, staging symbolic protests like coming to school dressed in black or boycotting examinations. ${ }^{57}$ The response to protests since November 2005 revealed the insecurity of the regime, and the extent of discontent beneath the surface. The discontent has now been augmented by the public's memory of the excessive nature of the violence used to suppress public demonstrations and opposition activity. ${ }^{58}$ But this situation, which now has continued for about a year, will not necessarily lead to a change of regime.

\section{Democratization: the enduring constraints}

An empirical study of the 2005 Ethiopian electoral process shows that indeed great strides were made towards a new democratic process. But the elections evidenced some serious flaws, especially in the counting stage, and probably did not reflect the preference of the people under free-andfair conditions. A balanced treatment of the complaints about contested constituencies in May-June 2005 and fair re-voting would have made all the difference.

A more general conclusion is that Ethiopian political culture is not yet free from its historical heritage of authoritarianism, elite rule, and patronage and that in this context a change of government and the ousting of the reigning party stand small chance in post-1991 Ethiopia. The political system has been reconstituted anew as one of neo-patrimonial governance reverting to old modes and techniques of control and an ideology of power as a commodity possessed by a new elite at the centre. The old grid of autocratic governance was resurrected, the system reproducing the limitations to democratic, consultative government and due electoral process.

56. One journalist said: 'We feel betrayed by democracy (...). It is as if the government encouraged us to speak our minds so that it would know who to grab when the time came'. Cited in M. Odenheimer, 'A dream defiled — the betrayal of Ethiopia's democracy', Washington Post, 17 December 2005.

57. Police responded by beating and arresting the pupils and issuing warnings against teachers and parents.

58. Also victimizing elderly women, mothers, and children. The government, however, announced an 'independent inquiry' on the violence [see 'Resolve to set up Independent Inquiry Commission part of efforts to ensure the rule of law - Ministry', Ethiopian Herald, 19 November 2005 <http://allafrica.com/stories/200511210142.html>]. Previous inquiry commissions on violent incidents rarely led to prosecution or conviction of any security force members or government officials. 
Other complicating factors, related to Ethiopia's ethno-regional diversity and the politics of division, add their weight to the post-election crisis. I mention two examples, based on recent incidents. In June 2005, some 2,000 people of Amhara descent were chased out from the Gida-Kiramo district in Eastern Wollega (Oromia region) by local people, accused of being 'CUD opposition supporters'. ${ }^{59}$ Local ruling party members and cadres reportedly incited the people, and the police did not act to stop the expulsion. The victims had built up a life there since the 1960s and had intermarried in the community. But they had to leave under threat and abandon all their possessions. This event is an ominous sign that the political conflicts in Ethiopia are being ethnicized: to be an 'Amhara' brands one as supporter of the CUD and to be a supporter of CUD or another opposition party brands one as suspect in the eyes of the ruling party or its loyalists ${ }^{60}$ CUD has prominent leaders from the Amhara-speaking population and happens to have a large following in the Amhara, Gurage, and some other areas, but does not have an 'ethnic programme', unless its aim to eventually rescind Article 39.1 of the Ethiopian constitution (which allows the secession of ethnic groups or 'nationalities') is seen as such. The ruling party supporters seem to want people to believe that the CUD party has one, and indeed, many ordinary people are persuaded by this discourse. As a result, the lives of innocents, seen as imaginary opponents, are destroyed. Although ethnic tensions exist, it bodes ill for intergroup relations and for the continued existence of the Ethiopian political order to make ethnic differences an issue in politics. The current government has done a lot to make ethnicity the discourse of politics in Ethiopia - perhaps with the good intention of giving rights to ethnic groups. The opposition parties, although drawing support more from certain ethnic groups than from others (but very little from the Tigrayans), have no ethnic agenda per se, and the election debates were not about this. Opposition parties did not deny ethno-regional and cultural rights, but aimed at more unified national and equitable policies. If they would have pursued an ethnic agenda, then divisions would have been even greater, with explosive consequences.

Another telling incident occurred in November 2005 and concerned violent confrontation between local Muslims and Orthodox Christians (Amhara, Oromo, and Gurage) in the town of Kore in southern Ethiopia. The Christians were for some reason all identified with the CUD opposition and apparently attacked and put to flight by Muslim residents,

59. See the message 'Kä 2000 bälay yäQinijiit Dägafiwoch Täsaddädu' ('More than 2,000 CUD supporters were made refugees') <http://www.mahder.com/index.php?name=amharic $>$ (21 October 2005) in Amharic.

60. The same mechanism was seen in earlier confrontations of government loyalist-activists with Oromo people claiming rights and usually declared to be 'OLF (the banned Oromo Liberation Front) supporters'. 
agitated by unknown forces. ${ }^{61}$ This is a major crime and a very worrisome indication that people are starting to use religion as a pretext for political violence. The consequences of such an approach will be disastrous for Ethiopia, where religion is usually kept out of politics, certainly on the local, community level. Such incidents reveal deep problems in Ethiopian politics, where elites are not averse to resorting to divide-and-rule tactics to maintain power.

The current democratization process is structurally and ideologically limited in that it is too closely supervised by the party in power, which - a fact often forgotten - is one advocating 'revolutionary democracy', not liberal democracy. ${ }^{62}$ Revolutionary democracy aims at the collective mobilization of the people, led from above by the party. It derives from a combination of Marxist and ethno-regional ideology and has no negotiated, evolutionary basis in Ethiopia. It was functional in the anti-Derg guerrilla struggle, but after the TPLF-EPRDF victory in 1991, it was imposed nationwide by default. It envisages the party as a vanguard political force, which is not inclined to compromise with opposition forces because it is convinced that it has the solution for everything. In the current system, multiparty elections thus do not appear to fundamentally threaten the existing power structure: the party-dominated executive branch of government (controlling the economy, the army, and the security forces) always retains strict control. Van de Walle's remark that: '. . . the multiparty system is being constructed in such a way that it does not threaten that control' also holds in Ethiopia. ${ }^{63}$ But, as events in the post-election period suggest, perhaps more than in other African countries today, the executive in Ethiopia is prepared to use coercive force to prevent change. In a practical sense, it thus seems that Ethiopian voters will have great difficulty in ever voting the existing government out of office, unless the ruling party succumbs to internal tensions (as it almost did in 2001), ${ }^{64}$ or when the perceived socio-political damage - domestic instability and external, donor-country pressure - becomes too great, or, finally, when it converts to democratic dialogue and develops an inclusive agenda geared to the national interest (the promise that the regime held out in the early years).

61. News item on the website <http://ethiopianreview.homestead.com> (28 November 2005). It could not immediately be checked against other sources.

62. In 2001, the Ethiopian prime minister Meles Zenawi stated in an ideological discussion piece for his party ('Basic questions of democracy in Ethiopia') that 'liberal democracy' is not possible in Ethiopia. See The Reporter (Amharic magazine) 4, 36 (May 2001). Later in 2001, an ideological document in Amharic was produced, called 'Revolutionary Democracy' (cf. note 6), outlining the ruling party's future strategy. Western embassies had (parts of) it translated, but how it changed their view on Ethiopian politics as a result of reading it is not clear.

63. N. Van de Walle, 'Presidentialism and clientelism in Africa's emerging party systems', Fournal of Modern African Studies 42, 2 (2003), p. 315.

64. See the interesting analysis by Paulos Milkias, 'The great purge and ideological paradox in contemporary Ethiopian politics', Horn of Africa 19, 1-4 (2001), pp. 1-99. 
The option for the latter is still there, and if taken, the current regime would enhance its historic prestige and acceptance in one blow.

\section{Conclusion: revisiting the neo-patrimonial model}

Looking back on 15 years of political reform, one notes that the democratization process has not resulted - perhaps cannot - in the political institutionalization of democracy. The resurrected neo-patrimonialist regime prevents this. Power is not sufficiently transparent, and a democratic polity, including a well-functioning and independent judiciary, acceptable to the wider public and that would survive the change of personnel, was not achieved. Ethiopia has a well-entrenched political machine dominated by a party that is not ready to let go of power - the stakes are simply too high. The party elite has dominated government policy since 1991, and a real option of elections resulting in government change is not yet available. In this, Ethiopian politics, although in a more coercive version, resembles that of many other African (post-colonial) states.

Although the neo-patrimonial approach provides an essential start to explain Ethiopian (African) politics, it nevertheless can be granted that the critiques of this theory have a point: it is a model that, although necessary, is not sufficient in explaining African political systems. There are additional factors ${ }^{65}$ such as the force of ideology, the inherited tradition of 'state capacity', the existence of professionalism in the bureaucracy and the civil service, and last but not least donor-country pressures and demands. In the Ethiopian case, these four elements are clearly present: there is a strong vanguard party ideology leading the political elite, and there are notable standards of professionalism in the bureaucratic institutions and a residual idea of state responsibility and intervention for the common good ${ }^{66}$ The role of donor-country political and financial support in keeping the government in place is also significant (although in the end the Ethiopian government treats the donors with indifference and ignored their calls for moderation and mediation). But I would argue that even in the relatively exceptional case of Ethiopia, the logic that subsumes these elements mentioned above is that of neo-patrimonial rule - the country and its politics are treated as the privileged domain of power holders who operate in an informal and often non-transparent manner, and over which the formal institutions do not have a decisive say. Changes in the formal institutional sphere (parliamentary votes or elections), or independent

65. O. Therkildsen, 'Understanding public management through neo-patrimonialism: a paradigm for all African seasons?', in U. Engel and G.R. Olsen (eds), The African Exception (Ashgate, Aldershot, 2005), pp. 49-50.

66. Most members of which indeed resisted the party loyalist principles and crony appointments that the leading party tried to introduce after 1991 . 
operation of the judiciary, are not 'allowed' in current conditions if the existing power network is threatened.

Another criticism of neo-patrimonialist approaches, is that underlining a point made by Hansen in a recent study of Cameroon, they do not sufficiently take into account '. . . the use of force and the recourse to coercion', that is, the use of violence that political actors/systems in Africa - and similar systems elsewhere - are prepared to take. ${ }^{67}$ Coercive force is a necessary if not central ingredient of many political systems with contested legitimacy. Political culture in Ethiopia suffers under the historic burden of violence used as a political means, still recognizable today, in both rhetoric and practice. ${ }^{68}$ This reflects a general problematic in countries with institutional and economic resource scarcity and zero-sum game politics, where conceptions of power are unitary and the idea of a loyal opposition has not taken root.

In current conditions in Ethiopia, the ruling elite, for various reasons, cannot envisage or permit a division of powers and is endangering a continuation of the democratization process. It might also be argued that a complex and divided country like Ethiopia 'needs' a strong or authoritarian regime. But the question is whether the course taken is a durable one, or whether the government would stand a better chance by returning to the road of democratizing the polity. This latter possibility is still there, although increasingly unlikely: the regime has become entrenched to the extent that power, ideology, and material interests have coagulated into a structure that inhibits democratization. From events so far, one can conclude that the consultation and inclusion of citizens, the 'broad masses', is neglected, if not considered irrelevant, in view of the vanguard role of the dominant party and the intricate political-economic power structure now established. As noted above, the distance between the rulers and the ruled has increased to remarkable proportions. In the campaign of 'restoring law and order' since early November 2005, all public protests were suppressed with violent means and mass arrest of supposed opponents and opposition, and also Ethiopian civil society organizations and information sources were tackled. Several (like the Mäčča-Tuläma Association among the Oromo people) had already been proscribed before, but since November, the association of free press journalists ${ }^{69}$ and a number of local NGOs were also threatened, another indication of the turn towards the centralist control of civic space. Following Gill's theory, this clampdown on civil society will seriously retard a transition to democratic politics. ${ }^{70}$

67. Hansen, 'The politics of personal relations', p. 222.

68. Cf. J. Abbink, 'Transformations of violence in twentieth-century Ethiopia: cultural roots, political conjunctures', Focaal. Tijdschrift voor Antropologie 25, (1995), pp. 57-77.

69. By January 2006, all independent newspapers had stopped appearing.

70. Gill, Dynamics of Democratization. 
Compared to other African countries, Ethiopia has a relatively strong state, inherited from Emperor Haile Sellassie and currently expanded with a large security apparatus, and a popular revolution leading to regime change is not likely at this point. But most observers, including donorcountry representatives, have now come to conclude that, in simple objective terms, the position of the incumbent government is seriously weakened despite its re-establishing some kind of order. There is no going back to things as they were before May 2005. Not only is the government's political legitimacy seriously at issue, but it is also engendering contradictions between governance and socio-economic development. Development would benefit from middle-class dynamics, legal security of property, transparency of policy, and social mobility. Ignoring these contradictions and the profound desire for change among the Ethiopian public might prevent it from actually carrying out many of its political and economic programmes. It could also generate sustained protest, growing insecurity, and durable instability, undermining a government's functioning and even endangering the basis of neo-patrimonial rule. The fact that, again, there are violent succession problems in the Ethiopian political system - already known in the time of the Zagwe dynasty (eleventh to thirteenth century) underlines the remarkable but tragic continuity of Ethiopian history.

\section{Bibliography of books and articles}

References to other sources, including interviews, archives, newspaper articles, websites and grey publications, are contained in relevant footnotes.

Note: Names of Ethiopian and Eritrean authors are conventionally cited in full on first name.

Abbink, J., 'Transformations of violence in twentieth-century Ethiopia: cultural roots, political conjunctures', Focaal. Tijdschrift voor Antropologie 25, (1995), pp. 57-77.

Abdullahi, Ahmednasir M., 'Article 39 of the Ethiopian constitution on secession and self-determination: a panacea to the nationality question in Africa?', Verfassung und Recht in Übersee 31, 4 (1998), pp. 440-55.

Alemayehu Geda and Befekadu Degefe, 'Conflict, post-conflict and economic performance in Ethiopia', in A.K. Fosu and P. Collier (eds), Post-Conflict Economies in Africa (Palgrave-Macmillan, New York, 2005), pp. 125-42.

Bates, R.H., Essays on the Political Economy of Rural Africa (Cambridge University Press, Cambridge, 1983).

Bates, R.H. (ed.), Towards a Political Economy of Development: A rational choice perspective (University of California Press, Berkeley, 1998).

Bratton, $\mathrm{M}$. and N. van de Walle, 'Neopatrimonial regimes and political transitions in Africa', World Politics 46, 4 (1994), pp. 453-89.

Bratton, M. and N. van de Walle, Democratic Experiments in Africa: Regime transitions in comparative perspective (Cambridge University Press, Cambridge, 1997).

Chabal, P. and J.-P. Daloz, Africa Works: Disorder as political instrument (Indiana University Press, Bloomington, and James Currey, Oxford, 1999). 
Donham, D.L., Marxist Modern: An Ethnographic history of the ethiopian revolution (University of California Press, Berkeley, and James Currey, Oxford, 1999).

Gill, G., The Dynamics of Democratization: Elites, Civil society and the transition process (Macmillan Press, London, 2000).

Hansen, K.F., 'The politics of personal relations: beyond neopatrimonial practices in northern Cameroon', Africa 73, 2 (2003), pp. 202-25.

Hyden, G. and M. Bratton (eds), Governance and Politics in Africa (Lynne Rienner, Boulder, CO, 1992).

Joireman, S. Fullerton, 1997. 'Opposition politics and ethnicity in Ethiopia: "we will all go down together" ', Fournal of Modern African Studies 35, 3 (1997), pp. 387-407.

Karlström, M., 'Imagining democracy: political culture and democratization in Buganda', Africa 66, 4 (1996), pp. 485-505.

Kidane Mengisteab, 'Ethiopia's ethnic-based federalism: 10 years after', African Issues 19, 1-2 (1996), pp. 20-6.

Lyons, T.S., 'Closing the transition: the May 1995 elections in Ethiopia', Fournal of Modern African Studies 34, 1 (1996), pp. 121-42.

Médard, J.-F., 'L'État néo-patrimonial en Afrique noire', in J.-F. Médard (ed.), États d'Afrique Noire: Formations, mécanismes et crise (Karthala, Paris, 1991), pp. 323-53.

Médard, J.-F., 'Patrimonialism, neo-patrimonialism and the study of the post-colonial state in Subsaharan Africa', in H.S. Marcussen (ed.), Improved Natural Resource Management - the role of formal organisations and informal networks and institutions (Institute of International Development Studies, Roskilde University, Roskilde, 1996), pp. 76-97.

Medhane Tadesse and J. Young, 'TPLF: reform or decline?', Review of African Political Economy 30, 97 (2003), pp. 389-403.

Milliken, J. (ed.), 'State failure, collapse and reconstruction', Development and Change 33, 5 (2002), pp. 753-74 [Special issue].

Paulos Milkias, 'The great purge and ideological paradox in contemporary Ethiopian politics', Horn of Africa 19, 1-4 (2001), pp. 1-99.

Okema, M., 1996. Political Culture in Tanzania (Edwin Mellen Press, Lewiston, NY, 1996).

Pausewang, S., K. Tronvoll, and L. Aalen (eds), Ethiopia since the Derg: a decade of democratic pretension and performance (Zed Press, London, 2002).

Smidt, W.G.C., 'Parlamentswahlen in Äthiopien', Afrika Spektrum 40, 2 (2005), pp. 319-30.

Therkildsen, O., 'Understanding public management through neo-patrimonialism: a paradigm for all African seasons?', in U. Engel and G.R. Olsen (eds), The African Exception (Ashgate, Aldershot, 2005), pp. 35-51.

Van de Walle, N., 'Presidentialism and clientelism in Africa's emerging party systems', Fournal of Modern African Studies 42, 2 (2003), pp. 297-321. 